\title{
DYNAMICS OF PRODUCTIVITY AND COST OF LABOUR IN ITALIAN MANUFACTURING FIRMS
}

\author{
Giulio Bottazzi* and Marco Grazzi† \\ *Institute of Economics, Scuola Superiore Sant'Anna, Pisa, Italy and \\ $\nmid$ Department of Economics, University of Bologna, Italy
}

\begin{abstract}
This paper studies the impact of size on labour cost and productivity for Italian manufacturing firms. The distributions of both labour cost and productivity display a wide support, even when disaggregated by sector of industrial activity. Further, both labour cost and productivity, when considered alone, are growing with the size of the firm. We investigate this relationship on a new set of data and we are able to show that once productivity differences among firms have been accounted for, size still retains a positive effect on cost of labour in most of the sectors considered.
\end{abstract}

Keywords: labor productivity, size-wage effect

JEL classification numbers: D21, J31, L11, L60

\section{INTRODUCTION}

The size-wage relation is known to hold for most countries and to be persistent over time. In this work we investigate if this relation still holds once productivity differences among firms are taken into account. The issue of the existence of a positive size-wage effect, while of general interest for industrial and labour economics, is particularly relevant for the Italian case due to the existence of a small size bias that characterizes the distribution of Italian firms as compared to those of other developed countries. In this work, we employ both non-parametric and parametric methods to show that, net of productivity effect, labour cost is, on average, increasing with the size of the firm. ${ }^{1}$

The evidence of a positive relation between employer size - measured as number of plants, employees, or sales - and wages has been reported by a number of different scholars starting

Correspondence: Marco Grazzi, Department of Economics, University of Bologna, Piazza Scaravilli 2, 40126 Bologna, Italy. Tel: +39-051-2098130; Fax: +39-051-2098493; Email: marco.grazzi@unibo.it. We thank Giovanni Dosi, Angelo Secchi, and Federico Tamagni for many useful discussions and comments at various stages of this work. We also thank Lawrence Kahn for useful suggestions. The statistical exercises which follow would not have been possible without the valuable help of the Italian Statistical Office (ISTAT) and in particular of Roberto Monducci and Andrea Mancini. G.B. acknowledges the support of the Italian Ministry of University and Research, grant PRIN 2009 "The growth of firms and countries: distributional properties and economic determinants", prot. 2009H8WPX5. The usual disclaimer applies.

${ }^{1}$ In this respect the present paper provides some complementary features to other works on Italian data (see, for instance, Bottazzi et al., 2002, 2007). We refer the interested reader to those works for an investigation of the properties of the size distributions of firms, their growth processes, and productivity dynamics. 
as early as Moore (1911). This regularity, though persistent over time and well documented for several countries (Davis and Haltiwanger, 1991; Main and Reilly, 1993; Brunello and Colussi, 1998; Arai, 2003; Lallemand et al., 2005), both at firm and establishment level, is not completely understood. In particular, the wage differential, while to some extent associated with observed differences in human capital, does not appear to be completely accounted for by them. In this respect Brown and Medoff (1989) find that among the various explanations attempting to account for the size-wage effect, the one receiving larger empirical support is the difference in workers' quality ${ }^{2}$ among size classes. The difference in quality however only accounts for roughly one-half of observed mean wage differentials. Hence, the search for an explanation to the observed size-wage gap has stimulated research in different directions. For instance, scholars have considered the relevance of corporate tournaments and compensation structure in determining wage differentials in small versus big enterprises (see, among others, Zàbojnik and Bernhardt, 2001; Hu, 2003). Based on these results, scholars of the field acknowledge that the analysis as such leaves the researcher uncomfortably unable to account for the part of the differential which is not explained by observable indicators of labour quality. Hence, they conclude that 'the employer size-wage effect remains a fact in need of an empirically based theory' (Brown and Medoff, 1989, p. 1057). Idson and Oi (1999), using more recent US census data still report a significant size-wage relation and they also find that output elasticity is bigger than wage elasticity to size variation. Also building on this result, they advance the hypothesis that 'employees at larger firms are more productive and hence command higher wages in a competitive labour market'.

Similar findings about the existence of 'a large, significant, and unexplained premium paid to workers of large employers' are reported by some works that rely on matched employeremployee data (see, for instance, Troske, 1999; Belfield and Wei, 2004; Muravyev, 2009).

Yet another stream of literature has tried to explain the size-wage effect by focusing on the hierarchical structure of organizations and how this structure might affect the total cost of labour in business firms. According to the 'hierarchical theory of the firm', (see, among others, Simon, 1957; Williamson, 1967; and more recently, Rajan and Zingales, 2001), the value and compensation for ability increases with the rank of a management position, and larger firms have proportionately more organizational layers than smaller firms (Meagher and Wilson, 2004).

Recent availability of firm level data has made the empirical investigation of this hypothesis possible. Findings in Delmastro (2002) and Meagher and Wilson (2004) support such conjecture. However, their results are based on sectoral surveys, thus only on a relatively small sample of firms. The analysis is extended to a large sample of Italian firms in Bottazzi and Grazzi (2010).

While following a similar spirit, in this paper we take a different empirical approach: we employ the census of Italian firms with more than 20 employees to investigate the existence and the pervasiveness of the size-wage effect in the Italian manufacturing industry. In order to avoid the potentially dangerous comparison of firms operating in different markets and facing very different cost structures, we perform our analysis at a disaggregated level, investigating the relation between the size of the firm, its cost of labour, and its workforce composition at the three-and four-digit sectoral level. In this respect the present work also contributes to the investigation of inter-industry wage differentials (see, for instance, Thaler, 1989). Due to space constraint, we can only present detailed results for an exemplar selection of sectors, appropriately chosen among the ones having the largest number of firms in order to roughly cover the different types of economic activities. These results confirm the existence of a significant and positive relation between the size of the firm and its unitary cost of labour.

\footnotetext{
${ }^{2}$ Typical proxies of workers' quality are education or years of experience.
} 
After a detailed presentation of the database in Section II, Section III tackles the relation between the cost of labour born by a firm, its productivity, and its size. Then in Section IV we propose a multivariate framework which allows us to account for the residual effect of size when contemporaneously conditioning on labour productivity. Section V concludes.

\section{DATA DESCRIPTION}

The database employed for the analyses, Micro.3, has been built with the collaboration between the Italian statistical office, ISTAT, and a group of LEM researchers from the Scuola Superiore Sant'Anna, Pisa. ${ }^{3}$ The database covers the period 1989-2004 and represents a development of the former Micro.1 dataset, which was based on the census of all the Italian firms with more than 20 employees conducted by ISTAT over the period 1989-97. Micro.3 embodies Micro.1, and extends it for seven years, by combining census data with information appearing in firms' financial statements. After performing this link, Micro.3 contains information about 134,625 Italian firms.

In the following, we are going to focus our empirical analysis only on firms in the manufacturing industry which, according to the NACE classification, are those belonging to the tabulation category D, that is, firms having their principal activity in sectors 15 to 37 (UNSD, 2002). After this selection we are left with a total of 97 three-digit sectors. Given this relatively large number, we cannot present a complete sector by sector study. Even if one considers the sectors with more companies, i.e. the ones with an average number of firms larger than 100 , their number remains higher than 20. Moreover, considering only the sectoral size as a selection variable would ultimately introduce biases in the adopted sample, with the possible lack of relevant activities. In order to avoid this effect, in the following analysis we will consider a representative collection of sectors, chosen among the most populous but built with the idea of possibly accounting for the variegated activities covered by the manufacturing classification.

The first column of every year in Table 1 reports the number of observations available in the sectors under investigation in 1989 and 2004. Notice that, as explained above, the possibility to combine census data to administrative sources resulted in a higher number of observations after 1997. The other columns of Table 1 report a first descriptive statistics, employment share per size class, that is purported at representing the existing differences, and their persistency, between industrial sectors. Consider for instance the sector of production and processing of meat (151); there a high proportion of employment is concentrated in the biggest firms (more than 250 employees) and such tendency always persists in the most recent years, when observations from a higher number of firms are available. On the contrary, in the sector of treatment and coating of metals (285), the highest proportion of employment is channelled through smaller firms. The intersectoral differences are in general persistent over time, with a relative tendency to observe higher employment share in bigger firms in more recent years. Quite obviously sectoral differences will affect the analysis of the relation between size of the firm and its labour cost and productivity.

For the analyses that follow, we need a proxy for size, labour cost, and productivity of the firm. We choose the number of employees as our proxy for firm size. Then, since our main focus here is on the productive efficiency of the Italian manufacturing sector, a natural proxy is to consider the bulk of expenditures related to workforce by every firm. This includes: (a) salary paid to employees (comprising wage, overtime pay, and bonus); (b) social security

\footnotetext{
${ }^{3}$ The database has been made available for work after careful censorship of individual information. More detailed information concerning the development of the database Micro.3 is in Grazzi et al. (2009).
} 
TABLE 1

Total number of firms per sector and employment share (percentages) per size class measured in terms of number of employees; selected 3-digit sectors in Manufacturing, 1989 and 2004

\begin{tabular}{|c|c|c|c|c|c|c|c|c|c|c|}
\hline \multirow[b]{2}{*}{ NACE sector } & \multicolumn{5}{|c|}{1989} & \multicolumn{5}{|c|}{2004} \\
\hline & Tot & $20-49$ & $50-99$ & $100-249$ & $250^{+}$ & Tot & $20-49$ & $50-99$ & $100-249$ & $250^{+}$ \\
\hline $\begin{array}{l}151 \text { - Production, } \\
\text { processing of } \\
\text { meat }\end{array}$ & 293 & 22.1 & 14.1 & 24.9 & 38.9 & 407 & 17.5 & 14.4 & 20.6 & 47.5 \\
\hline $\begin{array}{l}177 \text { - Knitted, } \\
\text { crocheted } \\
\text { articles }\end{array}$ & 450 & 32.9 & 22.6 & 21.6 & 22.9 & 251 & 16.4 & 20.4 & 22.8 & 40.4 \\
\hline $\begin{array}{l}182 \text { - Wearing } \\
\text { apparel, } \\
\text { accessories }\end{array}$ & 1357 & 26.0 & 18.8 & 22.1 & 33.1 & 1360 & 17.3 & 21.9 & 25.4 & 35.3 \\
\hline 193 - Footwear & 753 & 35.6 & 23.3 & 24.5 & 16.5 & 869 & 22.4 & 27.2 & 27.8 & 22.5 \\
\hline $\begin{array}{l}212 \text { - Articles of } \\
\text { paper, } \\
\text { paperboard }\end{array}$ & 334 & 22.2 & 19.7 & 27.3 & 30.8 & 548 & 18.8 & 18.6 & 26.2 & 36.2 \\
\hline $\begin{array}{l}222 \text { - Printing, } \\
\text { related services }\end{array}$ & 521 & 30.4 & 18.5 & 18.3 & 32.8 & 755 & 24.5 & 22.7 & 25.6 & 26.9 \\
\hline $\begin{array}{l}252 \text { - Plastic } \\
\text { products }\end{array}$ & 831 & 28.6 & 25.2 & 25.6 & 20.6 & 1569 & 22.8 & 23.9 & 32.7 & 20.4 \\
\hline $\begin{array}{l}266 \text { - Concrete, } \\
\text { plaster, cement }\end{array}$ & 388 & 31.9 & 25.3 & 23.6 & 19.2 & 573 & 26.4 & 27.4 & 27.5 & 18.7 \\
\hline $\begin{array}{l}281 \text { - Metal } \\
\text { products }\end{array}$ & 562 & 39.9 & 25.9 & 20.8 & 13.4 & 1145 & 34.6 & 29.0 & 27.4 & 8.7 \\
\hline $\begin{array}{l}285 \text { - Treatment } \\
\text { and coating of } \\
\text { metals }\end{array}$ & 608 & 51.6 & 28.0 & 18.1 & 2.4 & 1772 & 34.6 & 32.6 & 27.3 & 5.5 \\
\hline $\begin{array}{l}295 \text { - Special } \\
\text { purpose } \\
\text { machinery }\end{array}$ & 853 & 19.2 & 18.8 & 25.7 & 36.3 & 1185 & 19.3 & 23.4 & 24.0 & 33.2 \\
\hline 361 - Furniture & 1047 & 39.2 & 25.2 & 22.5 & 13.1 & 1434 & 19.3 & 26.3 & 27.5 & 26.7 \\
\hline
\end{tabular}

contribution paid by the employer (oneri sociali): and (c) retirement pay (Trattamento Fine Rapporto). We take the ratio between value added and number of employees as our proxy of (labour) productivity. If reliable data on capital stock and cost of capital use were available, one could have estimated Total Factor Productivity (TFP) as a proxy for firm-level productivity. Unfortunately, such data were not available to us. This should not result, however, in a large bias in regression coefficients. Let us explain how this is possible. First, the possibility to perform the same analysis at the four-digit level (Section IV. 1) allows us to confirm the findings at the three-digit level of disaggregation. In this respect, investigating the size-wage relation at a higher level of disaggregation lowers the risk of comparing firms that employ a different technology, as characterized for instance by different capital intensities, or different quality in the composition of the workforce. Second, other works (see, for instance, Foster et al., 2001) have recently shown on comparable firm level data that labour and multifactor productivity are closely correlated; in this respect also refer to the analysis in Haltiwanger et al. (1999). Third, in conclusion it could be that bigger firms are indeed characterized by a higher capital intensity. 
Plausibly, this will translate in higher labour productivity and also in higher cost of labour (more skilled employees are required when larger/newer machines have to be operated). The question however remains of whether and to what extent, in the Italian manufacturing sector, the increase in the latter exceeds the increase in the former. This is precisely the point of our paper.

In the analyses that follow, monetary variables are at constant prices, base year is 2000, and have been deflated employing the sectoral index of production price provided by ISTAT. ${ }^{4}$ Finally, to ease the interpretation of results, we also report all variables in thousands of Euro, even though, at the beginning of the period of observation, these reports were filed in Lira currency. ${ }^{5}$

\section{UNIVARIATE ANALYSIS: SIZE-WAGE AND SIZE-OUTPUT ELASTICITIES}

Before analysing the size-wage relationship it is instructive to look at the shape of the distributions of cost of labour as this variable will be at the core of our analysis. Whether there exists a large literature on size and productivity differences among firms (a comprehensive survey is that in Bartelsman and Doms, 2000; for Italy, refer to Bottazzi et al., 2007, 2005) there is much less evidence documenting differences in the cost of labour of firms. In this respect, we begin by showing the degree of heterogeneity in the cost of labour for firms belonging to the same three-digit sector. Figure 1 displays the kernel density estimate of labour cost in four different industries, knitting and crocheted articles (NACE 177), treatment and coating of metals (NACE 285), special purpose machinery (NACE 295), and furniture (361). Density is computed in 64 equispaced points with an Epanenchnikov kernel and the bandwidth is set according to the 'optimal routine' described in section 3.4 of Silverman (1986). Also notice that probability, on the $y$-axis, is on a log scale to enhance the representation of the tails of the distribution. For the same reason, cost of labour per employee, on the x-axis, is in logarithms so that it is possible to plot in the same graph firms with very different levels of cost of labour. Note that even if observations are deflated with production price index, the distributions display a noticeable shift to the right as we get to more recent years, suggesting an increase in the cost of labour in real terms. Figure 1 displays the remarkable coexistence of firms within the same sectors that are facing conspicuous differences in their cost of labour, with most spending firms facing an average labour cost which is seven time larger then the one of less spending firms. The sectors reported in Figure 1 are exemplary as the distributions display the same features in all other industries under analysis. Note also that there is no evidence of a shrinking of the support of the distribution over time, which suggests that the observed differences are persistent (more on this in Dosi et al., 2012). Further, the span of the support cannot even be exclusively attributed to the contemporaneous presence of different categories of workers. By way of an example, in Figure 2 we display, in deviation from the mean, the distribution of the firm average cost of labour per category of employment, blue- and white -collar workers. ${ }^{6}$ As can be seen, the huge differences in labour cost persist within the same category and the width of the original distribution cannot be exclusively ascribed to differences in workforce composition (for a more

\footnotetext{
${ }^{4}$ ISTAT, the Italian statistical office, provides many time series of the Italian economy online at: http://dati.istat.it/?lang=en.

${ }^{5}$ At the beginning of the period, the Italian currency with legal tender status was the Italian Lira whose exchange rate with the Euro was later fixed at $€ 1$ per 1936.27 Lira.

${ }^{6}$ Unfortunately, we cannot replicate this evidence for the latest years of the sample as in that period labour costs by employment categories are available only for firms with more than 100 employees, a rather small proportion of the sample. On the other hand, there is no reason to believe that the shape and, more importantly, the width of the two distributions significantly changed in more recent years.
} 

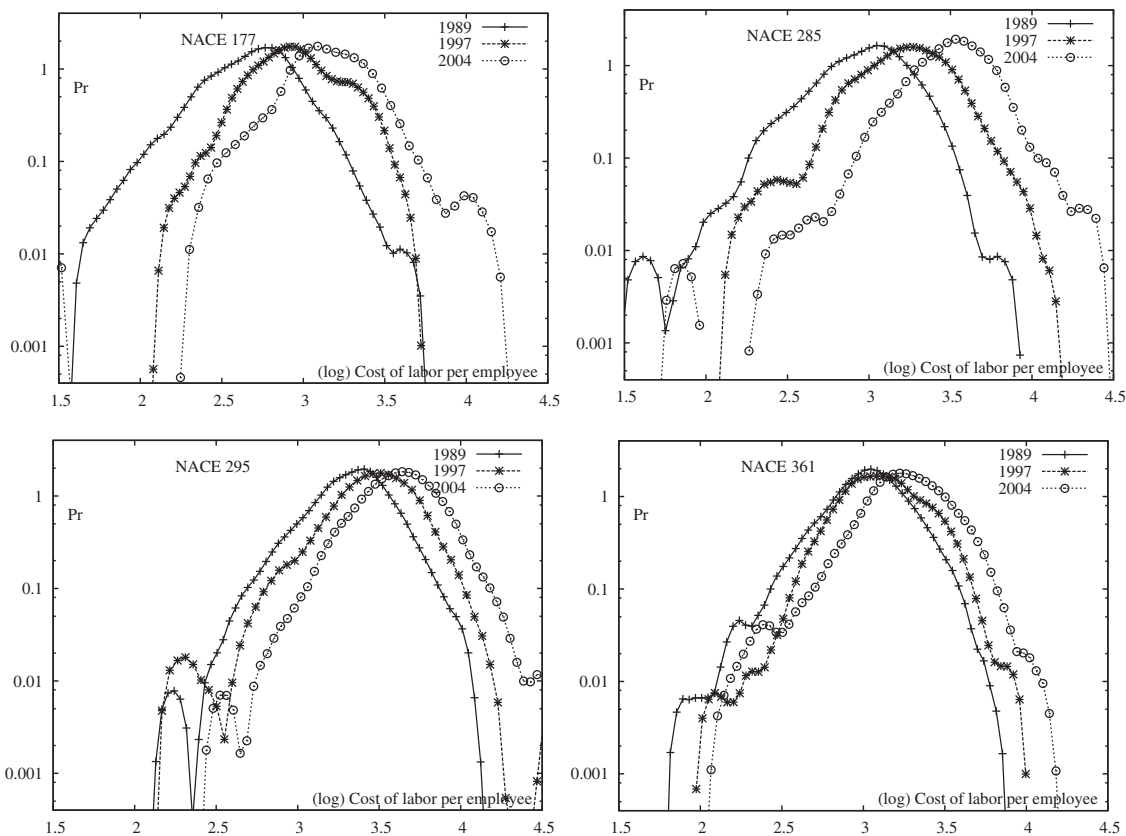

Fig. 1. Kernel density estimate of ( $\log )$ cost of labour per worker in crocheted articles, NACE 177; coating of metals, NACE 285; special purpose machinery, NACE 295; and manufacture of furniture, NACE 361. Data are deflated.
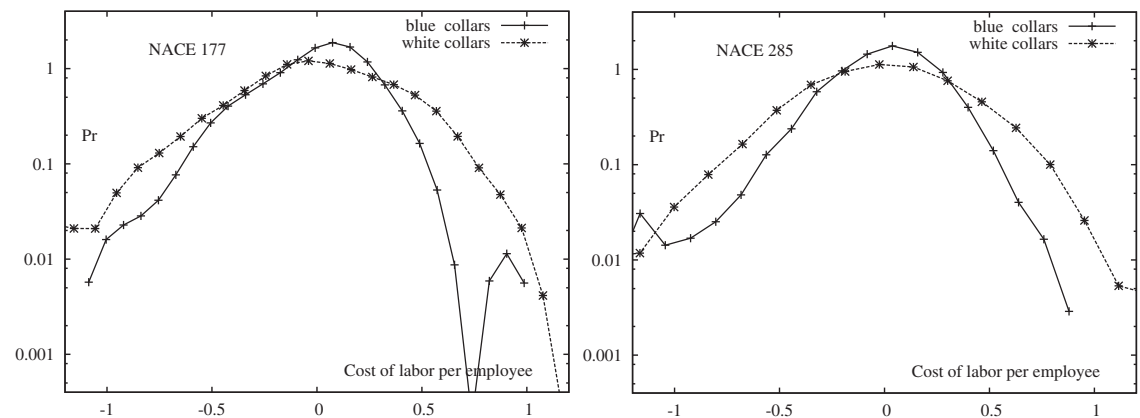

Fig. 2. Kernel density estimate of ( $\log )$ cost of labour per worker for blue- and white- collar workers in 1993, in deviation from the mean.

complete account of the workforce composition effect see the analysis in Bottazzi and Grazzi, 2010).

In order to investigate the source of this heterogeneity we start by analysing the relation between total cost of labour, $W$, and size of the firm as proxied by number of employees, $L$. If the cost of labour does not depend on the size of the firm, the labour total expenditure, $W$, grows proportionally with the number of employees, $L$. Consider the following scaling relation

$$
W \sim L^{1+\beta} .
$$



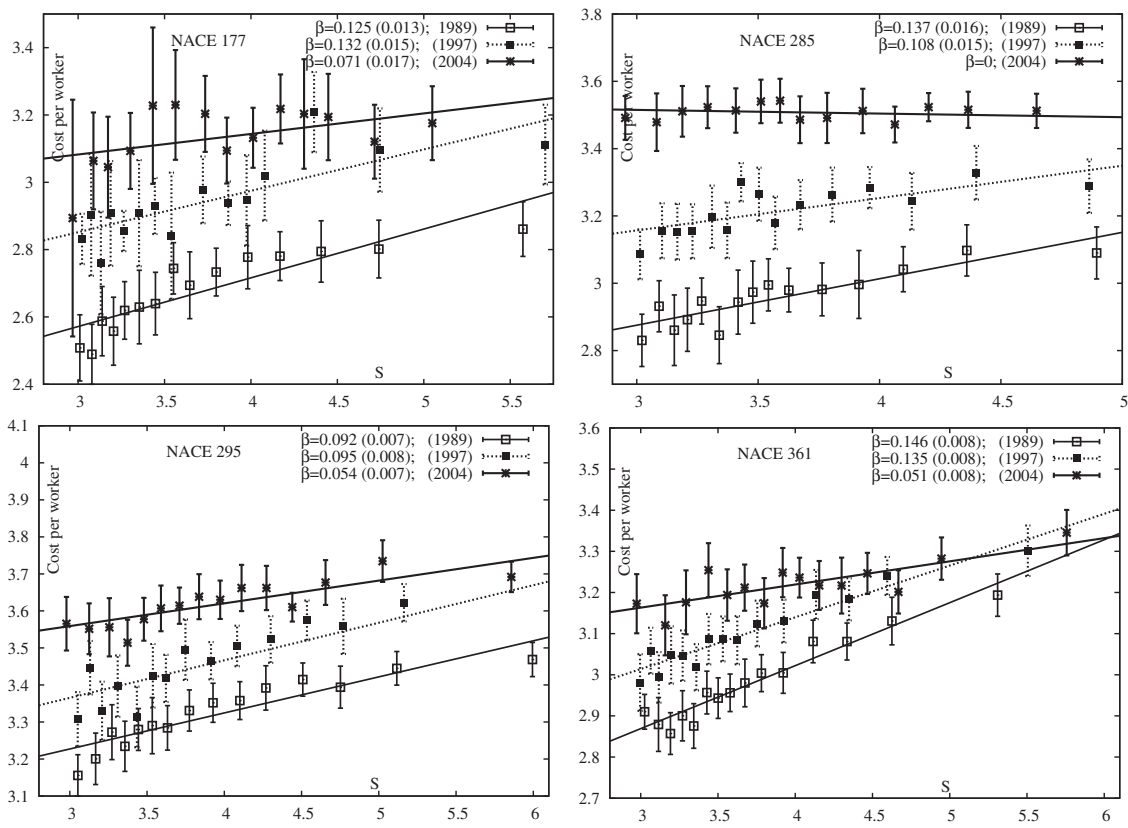

Fig. 3. Relation between size (as number of employees) and cost of labour in 1989 and 2004. Variables are in logs and deflated.

If $\beta>0$ then larger firms incur, in general, increased labour costs, while if $\beta<0$ the opposite happens. In order to capture these effects we fit a log-linear relation between the labour cost per employee $C=W / L$ and the number of employees, $L$, with the model

$$
c_{i}(t)=\alpha+\beta l_{i}(t)+\epsilon_{i}(t)
$$

where subscript $t$ identifies the year of interest and lower case symbols denote the logarithm of the original variables, that is $c=\log C$ and $l=\log L{ }^{7}$

Figure 3 exhibits binned scatter plots of $c$ vs $l$ for the same sectors analysed in the previous figures, namely knitting and crocheted articles (NACE 177) and treatment and coating of metals (NACE 285) together with the estimated relation. Table 2 reports coefficients for all sectors in the analysis. Since the residuals of OLS estimation display a Laplacian shape, the use of least absolute deviation (LAD) as a robust estimation technique (Huber, 1981) appears particularly suited. In general, a positive relation appears between labour cost per employee and size. Due to the small magnitude of standard errors, the relation is significant in almost all sectors considered. ${ }^{8}$ As such, this evidence suggests that labour cost per employee is increasing more than proportionally with size. Moreover, we also notice that the positive relation between size and wage is persistent over time, as the estimated coefficients are positive and significant both in 1989 and in 2004. In this respect we observe a tendency towards a relative reduction of the $\beta$ coefficient between the beginning and the end of the period. It would be of course very

\footnotetext{
${ }^{7}$ In this work we employ linear or log-linear functional forms for regressions. In principle, this is not an innocuous assumption, and needs to be tested. We have done so in previous works on similar data and such assumption is supported by empirical evidence; refer to Bottazzi et al. (2005), Bottazzi and Grazzi (2010), and Bottazzi et al. (2010).

${ }^{8}$ In this and in the following, regression standard errors are obtained through bootstrap using 200 independent replications.
} 
TABLE 2

Relation between size (as number of employees) and labour cost per employee in 1989 and 2004

\begin{tabular}{|c|c|c|c|c|c|c|}
\hline \multirow[b]{2}{*}{ NACE sector } & \multicolumn{3}{|c|}{1989} & \multicolumn{3}{|c|}{2004} \\
\hline & $\begin{array}{c}\alpha \\
\text { (stderr) }\end{array}$ & $\begin{array}{c}\beta \\
\text { (stderr) }\end{array}$ & $\begin{array}{l}R^{2} \\
O b s\end{array}$ & $\begin{array}{c}\alpha \\
\text { (stderr) }\end{array}$ & $\begin{array}{c}\beta \\
\text { (stderr) }\end{array}$ & $\begin{array}{l}R^{2} \\
O b s\end{array}$ \\
\hline 151 - Production, processing of meat & $\begin{array}{c}\mathbf{2 . 8 1 1} \\
(0.004)\end{array}$ & $\begin{array}{c}\mathbf{0 . 0 8 1} \\
(0.001)\end{array}$ & $\begin{array}{c}0.964 \\
293\end{array}$ & $\begin{array}{c}\mathbf{3 . 1 6 0} \\
(0.006)\end{array}$ & $\begin{array}{c}\mathbf{0 . 0 6 2} \\
(0.002)\end{array}$ & $\begin{array}{c}0.963 \\
360\end{array}$ \\
\hline 177 - Knitted, crocheted articles & $\begin{array}{c}\mathbf{2 . 2 2 9} \\
(0.005)\end{array}$ & $\begin{array}{c}\mathbf{0 . 1 2 5} \\
(0.001)\end{array}$ & $\begin{array}{c}0.957 \\
450\end{array}$ & $\begin{array}{c}\mathbf{2 . 8 4 4} \\
(0.009)\end{array}$ & $\begin{array}{c}\mathbf{0 . 0 7 1} \\
(0.002)\end{array}$ & $\begin{array}{c}0.956 \\
181\end{array}$ \\
\hline 182 - Wearing apparel, accessories & $\begin{array}{c}1.962 \\
(0.002)\end{array}$ & $\begin{array}{c}\mathbf{0 . 1 7 4} \\
(0.001)\end{array}$ & $\begin{array}{r}0.955 \\
1357\end{array}$ & $\begin{array}{c}\mathbf{2 . 5 4 6} \\
(0.005)\end{array}$ & $\begin{array}{c}\mathbf{0 . 1 3 0} \\
(0.001)\end{array}$ & $\begin{array}{c}0.945 \\
798\end{array}$ \\
\hline 193 - Footwear & $\begin{array}{c}\mathbf{2 . 1 6 2} \\
(0.005)\end{array}$ & $\begin{array}{c}\mathbf{0 . 1 4 5} \\
(0.001)\end{array}$ & $\begin{array}{c}0.960 \\
753\end{array}$ & $\begin{array}{c}\mathbf{2 . 7 0 7} \\
(0.008)\end{array}$ & $\begin{array}{c}\mathbf{0 . 1 0 3} \\
(0.002)\end{array}$ & $\begin{array}{c}0.961 \\
487\end{array}$ \\
\hline 212 - Articles of paper, paperboard & $\begin{array}{l}\mathbf{2 . 6 4 0} \\
(0.005)\end{array}$ & $\begin{array}{c}\mathbf{0 . 1 2 2} \\
(0.001)\end{array}$ & $\begin{array}{c}0.967 \\
334\end{array}$ & $\begin{array}{l}\mathbf{2 . 9 6 7} \\
(0.005)\end{array}$ & $\begin{array}{l}\mathbf{0 . 1 1 7} \\
(0.001)\end{array}$ & $\begin{array}{c}0.963 \\
437\end{array}$ \\
\hline 222 - Printing, related services & $\begin{array}{c}\mathbf{2 . 7 9 4} \\
(0.005)\end{array}$ & $\begin{array}{c}\mathbf{0 . 1 5 0} \\
(0.001)\end{array}$ & $\begin{array}{c}0.973 \\
521\end{array}$ & $\begin{array}{c}\mathbf{3 . 1 2 8} \\
(0.004)\end{array}$ & $\begin{array}{c}\mathbf{0 . 0 8 8} \\
(0.001)\end{array}$ & $\begin{array}{c}0.969 \\
493\end{array}$ \\
\hline 252 - Plastic products & $\begin{array}{c}\mathbf{2 . 6 5 2} \\
(0.003)\end{array}$ & $\begin{array}{c}\mathbf{0 . 1 2 0} \\
(0.001)\end{array}$ & $\begin{array}{c}0.969 \\
831\end{array}$ & $\begin{array}{l}\mathbf{3 . 0 3 9} \\
(0.002)\end{array}$ & $\begin{array}{l}\mathbf{0 . 1 0 0} \\
(0.001)\end{array}$ & $\begin{array}{c}0.975 \\
1129.00\end{array}$ \\
\hline 266 - Concrete, plaster, cement & $\begin{array}{l}\mathbf{2 . 8 3 9} \\
(0.007)\end{array}$ & $\begin{array}{c}\mathbf{0 . 0 8 5} \\
(0.002)\end{array}$ & $\begin{array}{c}0.954 \\
388\end{array}$ & $\begin{array}{c}\mathbf{3 . 0 7 1} \\
(0.008)\end{array}$ & $\begin{array}{c}\mathbf{0 . 0 7 7} \\
(0.002)\end{array}$ & $\begin{array}{c}0.959 \\
447\end{array}$ \\
\hline $281-$ Metal products & $\begin{array}{l}\mathbf{2 . 5 3 1} \\
(0.004)\end{array}$ & $\begin{array}{c}\mathbf{0 . 1 4 3} \\
(0.001)\end{array}$ & $\begin{array}{c}0.964 \\
562\end{array}$ & $\begin{array}{l}\mathbf{3 . 1 5 0} \\
(0.007)\end{array}$ & $\begin{array}{l}\mathbf{0 . 0 5 8} \\
(0.002)\end{array}$ & $\begin{array}{c}0.962 \\
619\end{array}$ \\
\hline 285 - Treatment \& coating of metals & $\begin{array}{c}\mathbf{2 . 4 9 0} \\
(0.007)\end{array}$ & $\begin{array}{c}\mathbf{0 . 1 3 7} \\
(0.002)\end{array}$ & $\begin{array}{c}0.958 \\
608\end{array}$ & $\begin{array}{c}\mathbf{3 . 5 1 9} \\
(0.004)\end{array}$ & $\begin{array}{l}0 \\
(0.001)\end{array}$ & $\begin{array}{l}0.968 \\
849\end{array}$ \\
\hline 295 - Special purpose machinery & $\begin{array}{c}\mathbf{2 . 9 6 8} \\
(0.003)\end{array}$ & $\begin{array}{c}\mathbf{0 . 0 9 2} \\
(0.001)\end{array}$ & $\begin{array}{c}0.968 \\
853\end{array}$ & $\begin{array}{l}\mathbf{3 . 4 0 8} \\
(0.003)\end{array}$ & $\begin{array}{c}\mathbf{0 . 0 5 4} \\
(0.001)\end{array}$ & $\begin{array}{l}0.965 \\
884\end{array}$ \\
\hline 361 - Furniture & $\begin{array}{c}\mathbf{2 . 4 4 6} \\
(0.004)\end{array}$ & $\begin{array}{c}\mathbf{0 . 1 4 6} \\
(0.001)\end{array}$ & $\begin{array}{c}0.962 \\
1047\end{array}$ & $\begin{array}{c}\mathbf{3 . 0 1 4} \\
(0.004)\end{array}$ & $\begin{array}{c}\mathbf{0 . 0 5 2} \\
(0.001)\end{array}$ & $\begin{array}{c}0.963 \\
921\end{array}$ \\
\hline
\end{tabular}

LAD estimates and bootstrapped standard errors in brackets. Constant price log variables; coefficients significant at the 0.05 level are in bold. See also Figure 3, left panel.

interesting to verify if this trend has continued up to a point in which the relation is no longer significant. Notice that equation (2) is the same as that used in Idson and Oi (1999) in which the authors also find evidence of a positive relation. Even if they do not run separate regressions for each industry as we do, the magnitude of the relation that they found is very close to ours.

While the slope of the fitted lines has only marginally diminished from 1989 to 2004, the intercepts display an outward shift. This is also apparent in the plots of Figure 3. Since the monetary variables in the analysis are already inflation-adjusted, such a shift is proportional to the sectoral average increase in the cost of labour in real terms. The assessment of such a trend, which goes beyond the scope of the present work, might shed some light on the sources of often claimed Italian competitiveness loss in recent years (Malgarini and Piga, 2006; Dosi et al., 2012).

The last column for each year of Table 2 reports the number of observations and the value of the coefficient of determination $R^{2}$ (McKean and Sievers, 1987) defined as

$$
R^{2}=\frac{\hat{L}}{\hat{L}+s_{95}(N-K-1)}
$$


where $\hat{L}$ is the estimated (minimal) log-likelihood of the model, $N$ is the number of observations, $K$ the number of estimated parameters and $s_{95}$ the 95 percent confidence interval of the median of the distribution of residuals. The latter is computed using the distribution free range of variation described in Hollander and Wolfe (1999) (see McKean and Schrader (1984) for a discussion about the efficiency of this method). We also computed the confidence level with which the hypothesis of no relationship (in this case $\beta=0$ ) can be rejected. This level is obtained by comparing $s_{95}$ with the asymptotic distribution of the ratio between the likelihood gain of the fully specified model and the model with only the constant. Since the null hypothesis was always rejected with confidence higher than 1 percent - in this and in all the following regressions - in the interest of space we decided not to report such statistics, which are however available upon request.

The width of the support for cost of labour in Figure 1 already informed us about the broad differences existing within three-digit sectors. Then, the estimates of the $\beta$ coefficients from equation (2) already provide a first account of such intra-industry heterogeneity. For instance, in the knitted and crocheted sector (NACE 177) in 1997 (top left plot of Figure 3), firms of smallest size benefit from a labour cost per employee, in per capita terms, which is roughly one third smaller than the one of largest firms. This 'spread' in the cost of labour might appear modest at first, but one has to bear in mind that most employment contracts in Italy are set according to nationwide agreements in the various industrial sectors. If one considers the plausible flattening effect of these regulations on the pay of employees, then such wage spreads are substantial. On the other hand, the fact that firms face rather different wage rates is well in tune with the evidence reported in Bottazzi et al. (2005) and Bottazzi et al. (2007) on the heterogeneity in the mix of inputs and in the level of labour productivity (on the persistency over time of such phenomena, see also Dosi and Grazzi, 2006). This result contributes to lend empirical support to a picture of pervasive and persistent heterogeneities characterizing business firms. At the same time, however, this implies that a careful investigation on the sources of the remarkable differences in labour cost at the sectoral level and of the size-wage relation has to encompass an analogous analysis of firms' productivity. Indeed, it could be the case that such a variability in the cost of labour finds its counterpart and it is entirely explained by correspondingly different levels in the productivity of firms (in this respect, see also Idson and Oi, 1999; Oi and Idson, 1999; and for more recent empirical evidence on UK, Faggio et al., 2007).

To investigate possible productivity differentials, we analyse the relation between the total value added produced by a firm, $V A$, and the number of its employees, $L$. If the productivity of labour does not depend on the size of the firms, we expect to find a proportional relation between these two variables. We try to capture possible deviations from the proportionality assumption by fitting a double log relation between labour productivity, $\Pi=V A / L$, and the number of employees, $L$

$$
\pi_{i}(t)=\alpha+\delta l_{i}(t)+\epsilon_{i}(t)
$$

where $\pi=\log \Pi$. If $\delta=0$, then the amount of value added produced per worker does not depend on the size of the firm. As shown by plots in Figure 4, this is not the case, and labour productivity does indeed depend on firm size through an increasing relation. The statistical significance of coefficients in Table 3 supports the hypothesis that bigger firms enjoy higher levels of labour productivity. As for the elasticity of wage to size, we notice that $\delta$, although positive and significant from the beginning to the end of the sample period, displays a relative decrease over time.

While we were able to find a positive relationship between the size of the firm and both its labour productivity, captured by coefficients $\delta$ in Table 3 , and the cost of labour per worker, captured by coefficients $\beta$ in Table 2, the separate inspection of these coefficients does not allow 

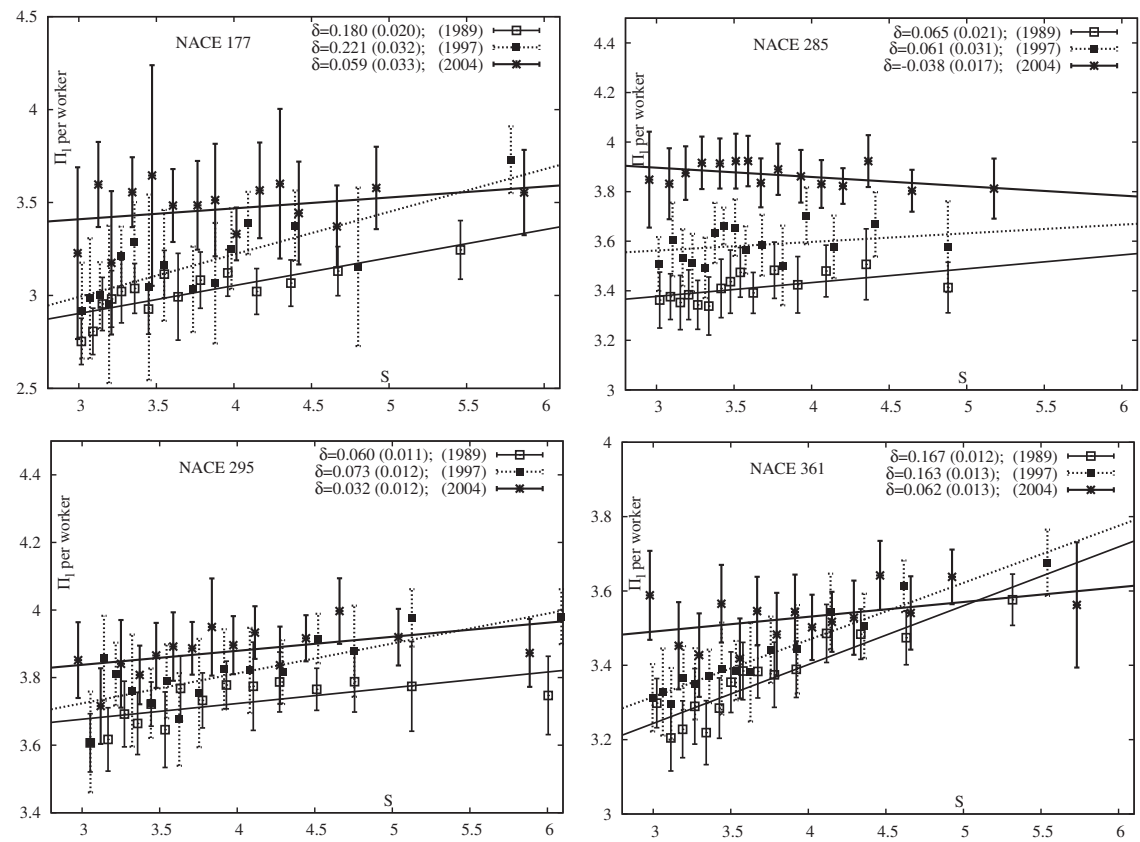

Fig. 4. Relation between size (as number of employees) and labour productivity, $\Pi_{l}$, as value added per worker for years 1989 and 2004. Variables are in logs and deflated.

us to discern if one of the two effects is overwhelming the other. That is, one cannot ascertain if the positive relation between size and productivity is sufficient to compensate a similar trend in the cost of labour, as it was the case in Idson and Oi (1999). There a simple comparison of the coefficients revealed a higher elasticity for labour productivity than for labour cost. In our case, it is instead necessary to consider a variable that provides a measure of the relation between cost of labour and productivity at different levels of firm size. The simplest approach is to consider as a proxy for unit labour cost the ratio between total labour cost and value added (see also Kravis and Lipsey, 1982), $U C=W / V A$. Given the very likely occurrence of value added that are positive and bigger than labour cost, most of the times unit labour cost takes values in the interval $(0,1]$ (and its logarithm in $(-\infty, 0])$. Quite obviously, a value of the ratio close to zero (one) suggests a very low (high) incidence of labour cost on value added, so that unit labour cost also provides a first account of distributive shares.

We investigate the relation between unit labour cost, as defined above, and firm size, fitting the log linear model

$$
\frac{c_{i}(t)}{\pi_{i}(t)}=\alpha+\gamma l_{i}(t)+\varepsilon_{i}(t)
$$

Coefficients for all sectors are reported in Table 4. It does not appear that a clear relation exists between the variables of interest. Indeed, the estimated slopes for $\gamma$ do not display an unambiguous pattern across sectors. Coefficients of the three-digit sectors for $\gamma$ are both positive and negative, also changing sign over time. Overall, there is a relatively higher proportion of positive coefficients, suggesting that at first, bigger firms have to bear, on average, a higher unit cost of labour, but this univariate approach is clearly weak in detecting this kind of relation. In order to identify robust relations one has to switch to more structured specifications. 
TABLE 3

Relation between size (as number of employees) and labour productivity in 1989 and 2004

\begin{tabular}{|c|c|c|c|c|c|c|}
\hline \multirow[b]{2}{*}{ NACE sector } & \multicolumn{3}{|c|}{1989} & \multicolumn{3}{|c|}{2004} \\
\hline & $\begin{array}{c}\alpha \\
\text { (stderr) }\end{array}$ & $\begin{array}{c}\delta \\
\text { (stderr) }\end{array}$ & $\begin{array}{l}R^{2} \\
O b s\end{array}$ & $\begin{array}{c}\alpha \\
\text { (stderr) }\end{array}$ & $\begin{array}{c}\delta \\
\text { (stderr) }\end{array}$ & $\begin{array}{c}R^{2} \\
O b s\end{array}$ \\
\hline \multirow[t]{2}{*}{151 - Production, processing of meat } & 3.244 & 0.086 & 0.939 & 4.010 & $-\mathbf{0 . 0 3 3}$ & 0.937 \\
\hline & $(0.009)$ & $(0.002)$ & 292 & $(0.014)$ & $(0.004)$ & 356 \\
\hline \multirow{2}{*}{177 - Knitted, crocheted articles } & 2.315 & 0.180 & 0.939 & 3.221 & 0.060 & 0.924 \\
\hline & $(0.009)$ & $(0.002)$ & 449 & $(0.019)$ & $(0.004)$ & 177 \\
\hline \multirow[t]{2}{*}{182 - Wearing apparel, accessories } & 2.050 & 0.203 & 0.934 & 3.019 & 0.088 & 0.901 \\
\hline & $(0.004)$ & $(0.001)$ & 1351 & $(0.009)$ & $(0.002)$ & 780 \\
\hline \multirow[t]{2}{*}{193 - Footwear } & 2.454 & 0.133 & 0.932 & 2.987 & 0.110 & 0.931 \\
\hline & $(0.008)$ & $(0.002)$ & 753 & $(0.012)$ & $(0.003)$ & 480 \\
\hline \multirow[t]{2}{*}{212 - Articles of paper, paperboard } & 3.162 & 0.110 & 0.951 & 3.349 & 0.130 & 0.937 \\
\hline & $(0.009)$ & $(0.002)$ & 334 & $(0.007)$ & $(0.002)$ & 432 \\
\hline \multirow{2}{*}{222 - Printing, related services } & 3.336 & 0.112 & 0.960 & 3.371 & 0.108 & 0.951 \\
\hline & $(0.009)$ & $(0.002)$ & 521 & $(0.005)$ & $(0.001)$ & 493 \\
\hline \multirow[t]{2}{*}{252 - Plastic products } & 3.220 & 0.095 & 0.942 & 3.608 & 0.058 & 0.957 \\
\hline & $(0.006)$ & $(0.001)$ & 829 & $(0.005)$ & $(0.001)$ & 1119 \\
\hline \multirow[t]{2}{*}{266 - Concrete, plaster, cement } & 3.375 & 0.068 & 0.942 & 3.776 & 0.024 & 0.936 \\
\hline & $(0.010)$ & $(0.003)$ & 388 & $(0.011)$ & $(0.003)$ & 445 \\
\hline \multirow[t]{2}{*}{281 - Metal products } & 3.183 & 0.069 & 0.949 & 3.375 & 0.082 & 0.946 \\
\hline & $(0.009)$ & $(0.003)$ & 560 & $(0.009)$ & $(0.002)$ & 614 \\
\hline \multirow[t]{2}{*}{285 - Treatment \& coating of metals } & 3.172 & 0.065 & 0.937 & 4.012 & 0.962 & 0.950 \\
\hline & $(0.009)$ & $(0.002)$ & 607 & $(0.005)$ & $(0.001)$ & 849 \\
\hline \multirow{2}{*}{295 - Special purpose machinery } & 3.478 & 0.060 & 0.952 & 3.766 & 0.032 & 0.948 \\
\hline & $(0.005)$ & $(0.001)$ & 852 & $(0.006)$ & $(0.001)$ & 878 \\
\hline \multirow[t]{2}{*}{361 - Furniture } & 2.733 & 0.167 & 0.951 & 3.294 & 0.063 & 0.949 \\
\hline & $(0.005)$ & $(0.001)$ & 1044 & $(0.006)$ & $(0.001)$ & 913 \\
\hline
\end{tabular}

LAD estimates and bootstrapped standard errors in brackets. Constant price log variables; coefficients significant at the 0.05 level are in bold. See also Figure 4, left panel.

\section{A MULTIVARIATE APPROACH}

In the previous section we showed that the size of the activity affects both cost of labour and productivity. However, by means of univariate analysis it is not possible to understand if any of the two effects is dominating. To this purpose, we consider a multivariate linear framework in which the impact of size on the cost of labour can be measured controlling, at the same time, for labour productivity. We express cost of labour per worker as depending on labour productivity and size,

$$
\ln \left(\frac{W_{i}}{L_{i}}\right)=\alpha_{1}+\alpha_{2} \ln \left(\frac{V A_{i}}{L_{i}}\right)+\alpha_{3} \ln \left(L_{i}\right)+\varepsilon_{i}
$$

where $\alpha_{2}$ and $\alpha_{3}$ capture the effect of productivity and size of the firm, respectively. The previous specification, with $L$ on both sides of the equation, implies that errors in labour input measures will automatically create biases in the estimated coefficients. For this reason we choose the 
TABLE 4

Relation between size (as number of employees) and unit labour cost in 1989 and 2004

\begin{tabular}{|c|c|c|c|c|c|c|}
\hline \multirow[b]{2}{*}{$N A C E$ sector } & \multicolumn{3}{|c|}{1989} & \multicolumn{3}{|c|}{2004} \\
\hline & $\begin{array}{c}\alpha \\
\text { (stderr) }\end{array}$ & $\begin{array}{c}\gamma \\
\text { (stderr) }\end{array}$ & $\begin{array}{l}R^{2} \\
O b s\end{array}$ & $\begin{array}{c}\alpha \\
\text { (stderr) }\end{array}$ & $\begin{array}{c}\gamma \\
\text { (stderr) }\end{array}$ & $\begin{array}{l}R^{2} \\
O b s\end{array}$ \\
\hline \multirow[t]{2}{*}{151 - Production, processing of meat } & -0.583 & $\mathbf{0 . 0 3 0}$ & 0.449 & -0.877 & 0.104 & 0.443 \\
\hline & $(0.070)$ & $(0.002)$ & 292 & $(0.006)$ & $(0.001)$ & 356 \\
\hline \multirow[t]{2}{*}{177 - Knitted, crocheted articles } & -0.224 & -0.023 & 0.310 & -0.173 & -0.040 & 0.407 \\
\hline & $(0.059)$ & $(0.002)$ & 449 & $(0.008)$ & $(0.002)$ & 177 \\
\hline \multirow[t]{2}{*}{182 - Wearing apparel, accessories } & -0.227 & -0.001 & 0.276 & -0.374 & 0.018 & 0.262 \\
\hline & $(0.029)$ & $(0.001)$ & 1351 & $(0.005)$ & $(0.001)$ & 780 \\
\hline \multirow[t]{2}{*}{193 - Footwear } & -0.239 & -0.004 & 0.394 & -0.376 & 0.020 & 0.306 \\
\hline & $(0.037)$ & $(0.001)$ & 753 & $(0.007)$ & $(0.002)$ & 480 \\
\hline \multirow[t]{2}{*}{212 - Articles of paper, paperboard } & -0.522 & 0.012 & 0.522 & -0.390 & -0.011 & 0.403 \\
\hline & $(0.056)$ & $(0.002)$ & 334 & $(0.006)$ & $(0.002)$ & 432 \\
\hline \multirow[t]{2}{*}{222 - Printing, related services } & -0.526 & 0.038 & 0.446 & -0.308 & -0.003 & 0.412 \\
\hline & $(0.046)$ & $(0.001)$ & 521 & $(0.004)$ & $(0.001)$ & 493 \\
\hline \multirow[t]{2}{*}{252 - Plastic products } & -0.644 & 0.043 & 0.451 & -0.533 & 0.033 & 0.475 \\
\hline & $(0.042)$ & $(0.001)$ & 829 & $(0.003)$ & $(0.001)$ & 1119 \\
\hline \multirow[t]{2}{*}{266 - Concrete, plaster, cement } & -0.589 & 0.032 & 0.542 & -0.567 & 0.025 & 0.422 \\
\hline & $(0.062)$ & $(0.001)$ & 388 & $(0.009)$ & $(0.002)$ & 445 \\
\hline \multirow[t]{2}{*}{281 - Metal products } & -0.569 & 0.056 & 0.409 & -0.277 & -0.007 & 0.457 \\
\hline & $(0.046)$ & $(0.001)$ & 560 & $(0.003)$ & $(0.001)$ & 614 \\
\hline \multirow[t]{2}{*}{285 - Treatment $\&$ coating of metals } & -0.742 & 0.090 & 0.510 & -0.462 & 0.035 & 0.401 \\
\hline & $(0.054)$ & $(0.002)$ & 607 & $(0.006)$ & $(0.002)$ & 849 \\
\hline \multirow[t]{2}{*}{295 - Special purpose machinery } & -0.526 & 0.038 & 0.411 & 0.318 & 0.013 & 0.357 \\
\hline & $(0.036)$ & $(0.001)$ & 852 & $(0.003)$ & $(0.001)$ & 878 \\
\hline \multirow[t]{2}{*}{361 - Furniture } & -0.352 & -0.001 & 0.510 & -0.222 & -0.023 & 0.403 \\
\hline & $(0.034)$ & $(0.001)$ & 1044 & $(0.003)$ & $(0.001)$ & 913 \\
\hline
\end{tabular}

LAD estimates and bootstrapped standard errors in brackets. Constant price log variables; coefficients significant at the 0.05 level are in bold.

following alternative specification

$$
\ln \left(W_{i}\right)=\alpha_{1}+\alpha_{2} \ln \left(V A_{i}\right)+\phi \ln \left(L_{i}\right)+\varepsilon_{i}
$$

where $\phi=\left(\alpha_{3}-\alpha_{2}+1\right)$.

Given our interest in the residual effect of size on cost of labour, $\alpha_{3}$, we first estimate $\phi$ from equation (7) and then compute $\alpha_{3}$ as a difference.

Table 5, as for the previous regressions, reports estimated (LAD) coefficients for 1989 and 2004. The coefficient $\alpha_{2}$ which accounts for the effect of total value added on total labour cost has the expected positive sign. On average, an increase in value added per worker bears a corresponding higher cost of labour for the firm. More interesting to the purpose of our analysis is the role of $\alpha_{3}$, the coefficient accounting for the residual impact of firm size on cost of labour. This coefficient is positive and significant for all sectors. We can conclude that a size-wage relation appears even when controlling for productivity differences among firms. Notice that our model contains logs on both dependent and independent variables, so that the reported coefficients should be interpreted as elasticities. For instance, in sector 151 (production and process of meat) a difference of 20 percent in labour productivity between firms of the same size 


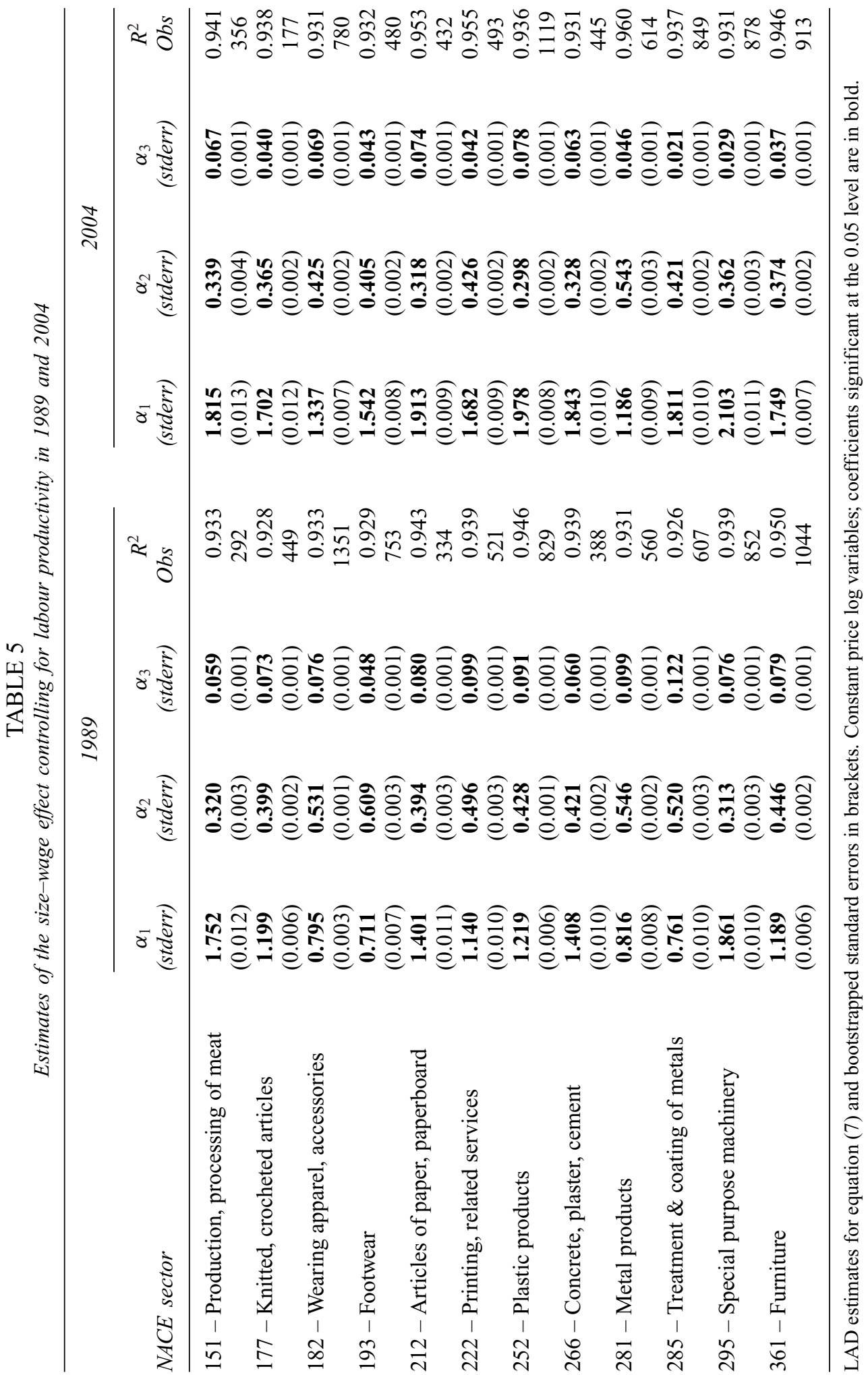


is associated with a difference in labour cost of about 7 percent. If the labour cost is the same, but sizes differ by 20 percent, the difference in wages is around 1 percent. This seems a tiny number, but considering that firm size spans several order of magnitude, it could still generate important effects. A firm with 1000 employees faces, on average, a cost of labour which is 14 percent larger than the one faced by a firm of 100 employees and with the same productivity level. Moreover, notice that the estimates reported in Table 5 are relatively stable over time, so that there is no evidence that this residual size-wage effect is vanishing over time.

In the multivariate specification of equations (6) and (7) we do not control for different production inputs, as, for instance, different capital productivities, and we are not making any statement on some generic measures of productivity, i.e. TFP, or on the relation between such proxy of productivity and size. This investigation would indeed lie well beyond the scope of this work. ${ }^{9}$ Thus it is still possible that the increased cost of labour at larger firms is somehow compensated by a lower cost of capital - or other inputs of production - and higher capital intensities, as for instance reported in Idson and Oi (1999). In any case, however, this effect, even if present, does not translate into an increase of value added per worker large enough to account for the increased cost of labour. As such our point remains valid.

Notice also that, although we do not condition here on employee characteristics, such as education, experience and the like, we do control for the relation between productivity and labour cost, that is exactly the assumed economic outcome ultimately resulting from the cumulated effect of the heterogeneous skills in the workforce. As such, the evidence emerging from Table 5 has to be interpreted as supportive of the hypothesis of a relative advantage of smaller firms over bigger ones in terms of the average cost of labour. These findings appear promising for a better understanding of the causes of constraints to growth of business firms, especially when jointly addressed with the troubles hindering firm growth and stemming from the limited access to the credit market of many SME firms (in this respect, see also Bottazzi et al., 2011).

\section{IV.1 Analyses on four-digit sectors}

The analyses above document the existence of a size-wage effect for Italian firms in three-digit sectors. In this respect an obvious concern is that these sectors might be composed of firms that are not involved in the same production activity. If this were the case, differences in productivity levels among firms would not point to 'real' differences in technical efficiencies, but they would be the result of a rather approximate comparison of firms that are not producing the same products. In order to account for such a possibility, we replicate the analyses previously performed at three-digit sectors on a selection of four-digit industrial sectors. To this purpose we pick, for every three-digit sector employed, the nested four-digit industry with the largest number of observations. This is the first work presenting results at the four-digit level of sectoral disaggregation for Italy. Table 6 reports the NACE code, the name of the sectors, the total number of observations in 1989 and 2004, and the size distributions of firms in those two years. Comparison with Table 1, reporting the same statistics for three-digit sectors, shows that the number of observations is significantly smaller once we pick the nested four-digit sector with the biggest number of observations. Also the size distribution of firms is affected. Take for instance the sector of Production of meat and poultrymeat products (NACE 1513). In this industry there are only 100 (211) firms in 1989 (2004) and there is a much smaller share of large firms (250 employees or more) than in the corresponding three-digit sector.

\footnotetext{
${ }^{9}$ For these and other issues, see Bottazzi et al. (2005).
} 
TABLE 6

Total number of firms per sector and employment share (percentages) per size class measured in terms of number of employees; selected 4-digit sectors in manufacturing, 1989 and 2004

\begin{tabular}{|c|c|c|c|c|c|c|c|c|c|c|}
\hline \multirow[b]{2}{*}{ NACE sector } & \multicolumn{5}{|c|}{1989} & \multicolumn{5}{|c|}{2004} \\
\hline & Tot & $20-49$ & $50-99$ & $100-249$ & $250^{+}$ & Tot & $20-49$ & $50-99$ & $100-249$ & $250^{+}$ \\
\hline $\begin{array}{l}1513 \text { - Production of } \\
\text { meat, poultrymeat } \\
\text { products }\end{array}$ & 100 & 16.6 & 15.8 & 35.3 & 32.3 & 211 & 27.2 & 20.0 & 29.4 & 23.4 \\
\hline $\begin{array}{l}1772 \text { - Knitted, } \\
\text { crocheted pullovers, } \\
\text { cardigans }\end{array}$ & 117 & 24.8 & 31.6 & 24.4 & 19.2 & 160 & 33.5 & 24.7 & 21.5 & 20.3 \\
\hline $\begin{array}{l}1822 \text { - Manufacture } \\
\text { of other outerwear }\end{array}$ & 307 & 10.7 & 13.9 & 25.0 & 50.4 & 864 & 27.9 & 18.5 & 19.9 & 33.4 \\
\hline $\begin{array}{l}1930 \text { - Manufacture } \\
\text { of footwear }\end{array}$ & 332 & 24.9 & 23.4 & 29.6 & 22.0 & 868 & 40.1 & 22.6 & 20.2 & 16.9 \\
\hline $\begin{array}{l}2121 \text { - Household, } \\
\text { sanitary goods, } \\
\text { toilet requisites }\end{array}$ & 109 & 20.6 & 23.9 & 25.3 & 30.3 & 251 & 24.1 & 17.2 & 28.2 & 30.0 \\
\hline 2222 - Printing n.e.c & 213 & 18.8 & 15.5 & 18.4 & 47.3 & 515 & 33.5 & 20.6 & 19.3 & 26.5 \\
\hline $\begin{array}{l}2524 \text { - Manufacture } \\
\text { of other plastic } \\
\text { products }\end{array}$ & 310 & 34.4 & 28.3 & 27.5 & 9.7 & 877 & 38.9 & 25.9 & 24.3 & 10.4 \\
\hline $\begin{array}{l}2663 \text { - Manufacture } \\
\text { of ready-mixed } \\
\text { concrete }\end{array}$ & 59 & 45.3 & 26.2 & 28.4 & 0.0 & 175 & 42.4 & 23.4 & 9.8 & 24.4 \\
\hline $\begin{array}{l}2812 \text { - Builders } \\
\text { carpentry and } \\
\text { joinery of metal }\end{array}$ & 50 & 55.6 & 32.2 & 12.2 & 0.0 & 236 & 55.0 & 21.6 & 19.2 & 4.2 \\
\hline $\begin{array}{c}2852-\text { General } \\
\text { mechanical } \\
\text { engineering }\end{array}$ & 268 & 54.0 & 25.4 & 18.1 & 2.5 & 1283 & 57.3 & 24.2 & 15.1 & 2.8 \\
\hline $\begin{array}{l}2954 \text { - Machinery for } \\
\text { textile, apparel, } \\
\text { leather prod. }\end{array}$ & 133 & 19.4 & 27.5 & 28.7 & 24.4 & 226 & 28.2 & 23.5 & 20.1 & 28.2 \\
\hline $\begin{array}{l}3611 \text { - Manufacture } \\
\text { of chairs and seats }\end{array}$ & 99 & 33.3 & 21.1 & 31.9 & 13.7 & 365 & 30.0 & 19.1 & 13.1 & 37.4 \\
\hline
\end{tabular}
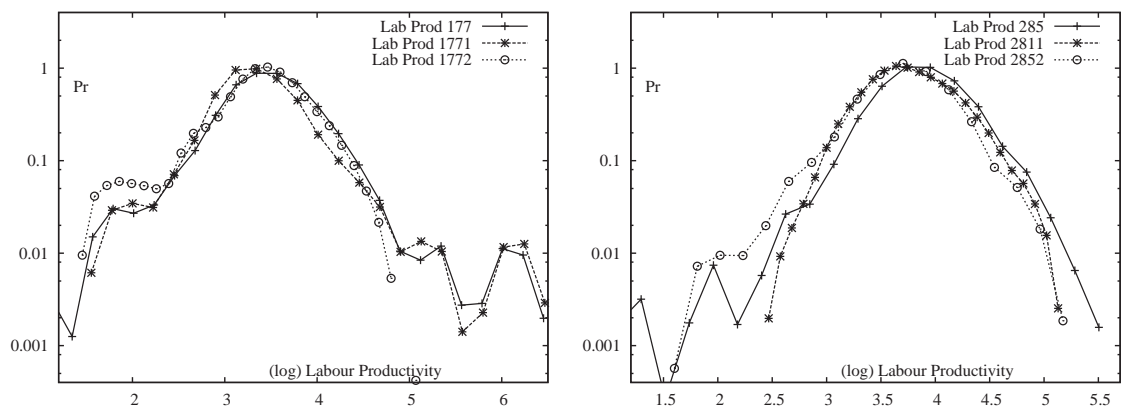

Fig. 5. Distribution of labour productivity for 3-digit and two nested 4-digit industries, year 2004. 


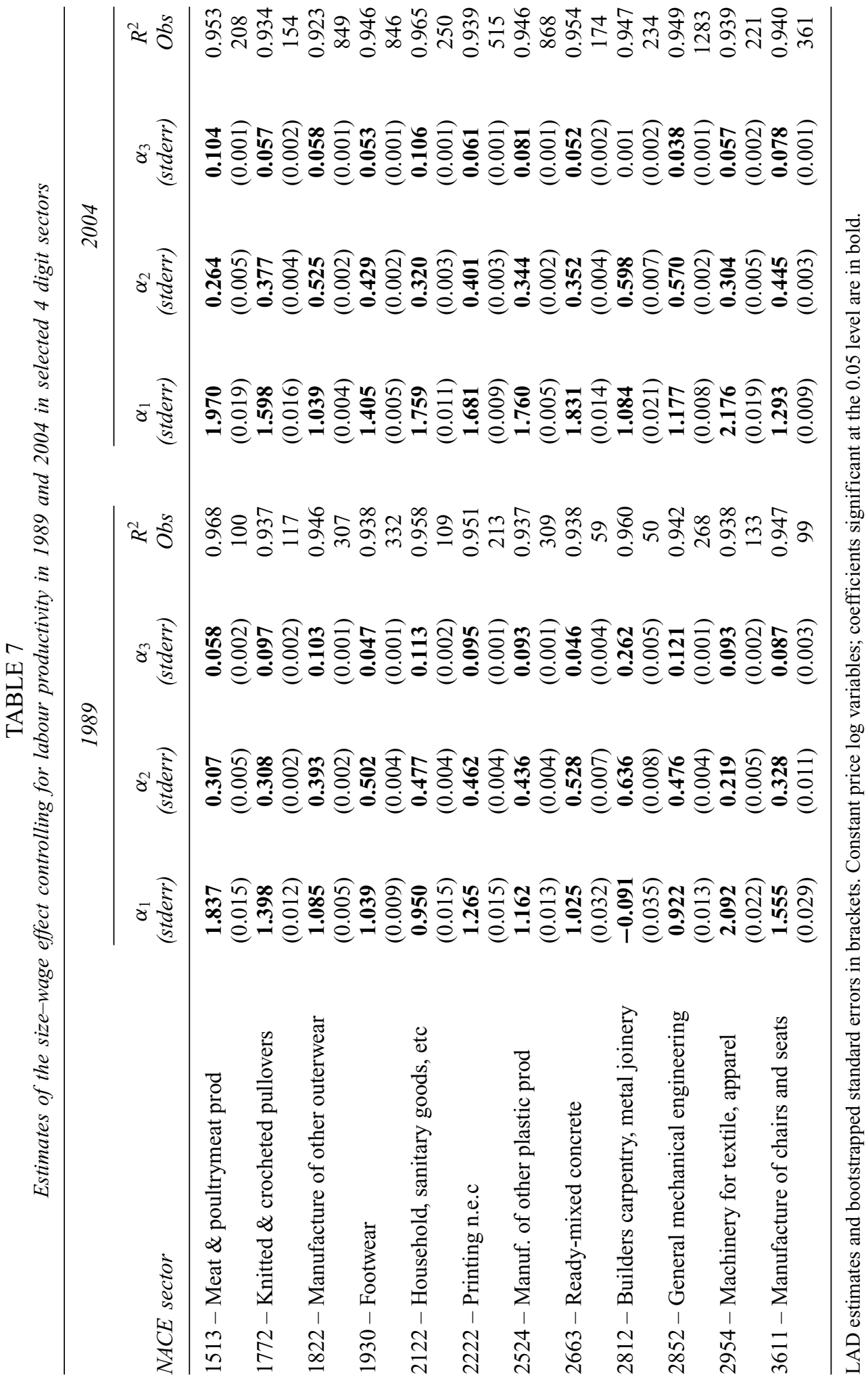


The distributional effect of disaggregation is much less significant when the production efficiency is concerned. Plots in Figure 5 display the distribution of labour productivity for a three-digit sector and two nested four-digit industries in 2004. Remarkably, the support of the distribution does not shrink much when going from three- to four-digit industrial classification. As discussed in Dosi and Grazzi (2006), this is a general phenomenon, which suggests that the observed heterogeneity is rather an intrinsic property of industries, no matter what is the chosen level of disaggregation.

We replicate regressions of equations (2), (4), and (5) on the selection of four-digit sectors, and since they do not display relevant differences with the previous evidence at the three-digit level, we do not include those tables, which are however available upon request.

The estimation of equation (7) is more crucial for the point we make in this work about the size-wage relation, hence we report results at the four-digit level in Table 7. Notice that both the sign and the magnitude of all coefficients $\left(\alpha_{1}, \alpha_{2}, \alpha_{3}\right)$ are similar to those in Table 5 . In particular, $\alpha_{3}$, the coefficient accounting for the residual impact of firm size on cost of labour, is positive and significant for all sectors, with the only exception of Manufacture of builders carpentry and joinery of metal (NACE 2812). As a result, also at a higher level of sectoral disaggregation it is possible to confirm the finding of a positive relation between the size of the firm, as proxied by the number of employees, and cost of labour per employee. Such a relation is robust also when controlling for productivity differences among firms.

\section{CONCLUSIONS}

In this paper we have shown the existence of a size-wage effect for Italian manufacturing firms (cf. Figure 3 and Table 5). This is a robust regularity as it holds both over time - almost two decades - and across all sectors of analysis. As such our results contribute both to the size-wage literature (Brown and Medoff, 1989; Idson and Oi, 1999) and to the investigation of inter-industry wage differentials (Thaler, 1989). Further and probably also more relevant for the understanding of the size-wage effect, we show that such a relation still exists once we explicitly account for the different levels of labour productivity that characterize firms operating at different scales. That is, the size-wage effect does not vanish when controlling for different productivities among firms. Also it does not appear that such a relation is fading away, as the estimated coefficients are pretty stable over time.

Overall, our results are supportive of the size-wage 'puzzle' as found also in other empirical works (as, for instance, in Brown and Medoff, 1989; Troske, 1999; Belfield and Wei, 2004). In particular, we are able to test for this relation without having to resort to proxies capturing the capabilities and skills of workers, but directly including labour productivity in our analysis. This, we believe, further strengthen our findings which hold both at three- and four-digit level of sectoral disaggregation.

Finally, the empirical evidence we provide in the paper is coherent with the theoretical explanation put forward by Idson and Oi (1999) according to which employees at larger firms are more productive and hence command higher wages in a competitive labour market. In this respect, we are able to show that, at least for Italy, controlling for different labour productivities does not completely extinguish the size-wage effect so that the higher cost of employment in larger companies is not fully explained by the increased efficiency in the use of labour. 


\section{REFERENCES}

Arai, M. (2003). 'Wages, profits, and capital intensity: evidence from matched worker-firm data', Journal of Labour Economics, 21, pp. 593-618.

Bartelsman, E. J. and Doms, M. (2000). 'Understanding productivity: lessons from longitudinal microdata', Journal of Economic Literature, 38, pp. 569-94.

Belfield, C. R. and Wei, X. (2004). 'Employer size-wage effects: evidence from matched employer-employee survey data in the UK', Applied Economics, 36, pp. 185-93.

Bottazzi, G., Cefis, E. and Dosi, G. (2002). 'Corporate growth and industrial structure. Some evidence from the Italian manufacturing industry', Industrial and Corporate Change, 11, pp. 705-23.

Bottazzi, G., Grazzi, M. and Secchi, A. (2005). 'Characterizing the production process: a disaggregated analysis of Italian manufacturing firms', Rivista di Politica Economica, JanFeb, pp. 243-70.

Bottazzi, G., Cefis, E., Dosi, G. and Secchi, A. (2007). 'Invariances and diversities in the evolution of Italian manufacturing industry', Small Business Economics, 29, pp. 137-59.

Bottazzi, G., Dosi, G., Jacoby, N., Secchi, A. and Tamagni, F. (2010). 'Corporate performances and market selection: some comparative evidence', Industrial and Corporate Change, 19, pp. 1953-96.

Bottazzi, G. and Grazzi, M. (2010). 'Wage-size relation and the structure of work-force composition in Italian manufacturing firms', Cambridge Journal of Economics, 34, pp. 649-69.

Bottazzi, G., Grazzi, M., Secchi, A. and Tamagni, F. (2011). 'Financial and economic determinants of firm default', Journal of Evolutionary Economics, 21, pp. 373-406.

Brown, C. and Medoff, J. (1989). 'The employer size-wage effect', Journal of Political Economy, 97, pp. 1027-59.

Brunello, G. and Colussi, A. (1998). 'The employer size-wage effect: evidence from Italy', Labour Economics, 5, pp. 217-30.

Davis, S. J. and Haltiwanger, J. (1991). 'Wage dispersion between and within U.S. manufacturing plants: 1963-86', Brookings Paper on Economic Activity, Microeconomics, 1991, pp. 115200.

Delmastro, M. (2002). 'The determinants of the management hierarchy: evidence from Italian plants', International Journal of Industrial Organization, 20, pp. 119-37.

Dosi, G. and Grazzi, M. (2006). 'Technologies as problem-solving procedures and technologies as input-output relations: Some perspectives on the theory of production', Industrial and Corporate Change, 15, pp. 173-202.

Dosi, G., Grazzi, M., Tomasi, C. and Zeli, A. (2012). 'Turbulence underneath the big calm: What is happening behind the flat trend of productivity in Italy', Small Business Economics Journal, 39, pp. 1043-67.

Faggio, G., Salvanes, K. and Reenen, J. V. (2007). 'The evolution of inequality in productivity and wages: panel data evidence', NBER Working Papers 13351. National Bureau of Economic Research, Inc.", pp. 30372, Chicago: University of Chicago Press.

Foster, L., Haltiwanger, J. and Krizan, C. J. (2001). 'Aggregate productivity growth: lessons from microeconomic evidence', in C. R. Hulten, E. R. Dean and M. J. Harper (eds), New Developments in Productivity Analysis, pp. 303-72, Chicago: University of Chicago Press.

Grazzi, M., Sanzo, R., Secchi, A. and Zeli, A. (2009). 'Micro.3. Some notes on the development of the integrated system of data 1989-2004', Documenti no. 11, ISTAT.

Griliches, Z. and Mairesse, J. (1999). 'Production functions: the search for identification', in Steiner, S. (ed.), Econometrics and Economic Theory in the Twentieth Century: The Ragner Frisch Centennial Symposium, Cambridge: Cambridge University Press.

Haltiwanger, J. C., Lane, J. I. and Spletzer, J. R. (1999). 'Productivity differences across employers: the roles of employer size, age, and human capital', American Economic Review, 89, pp. 94-8. 
Hollander, M. and Wolfe, D. A. (1999). Nonparametric Statistical Methods, 2nd edition, New York, Chichester: John Wiley \& Sons.

$\mathrm{Hu}$, L. (2003). 'The hiring decisions and compensation structures of large firms', Industrial and Labour Relations Review, 56, pp. 663-81.

Huber, P. J. (1981). Robust Statistics, New York: Wiley.

Idson, T. L. and Oi, W. Y. (1999). 'Workers are more productive in large firms', American Economic Review, 89, pp. 104-08.

Kravis, I. B. and Lipsey, R. E. (1982). 'The location of overseas production and production for export by U.S. multinational firms', Journal of International Economics, 12, pp. 201-23.

Lallemand, T., Plasman, R. and Rycx, F. (2005). 'The establishment-size wage premium: evidence from European countries', IZA Discussion Papers 1569.

Main, B. G. M. and Reilly, B. (1993). 'The employer size-wage gap: evidence from Britain', Economica, 60, pp. 125-42.

Malgarini, M. and Piga, G. (eds). (2006). Capital Accumulation, Productivity and Growth, Basingstoke: Palgrave Macmillan.

McKean, J. W. and Schrader, R. M. (1984). 'A comparison of methods for studentizing the sample median', Communications in Statistics - Simulation and Computation, 13, pp. $751-73$.

McKean, J. W. and Sievers, G. L. (1987). 'Coefficients of determination for least absolute deviation analysis', Statistics \& Probability Letters, 5, pp. 49-54.

Meagher, K. J. and Wilson, H. (2004). 'Different firm size effects on wages for supervisors and workers', Economics Letters, 84, pp. 225-30.

Moore, H. L. (1911). Laws of Wages: An Essay in Statistical Economics, History of Economic Thought Books, McMaster University Archive for the History of Economic Thought.

Muravyev, A. (2009). 'Employer size, wages and unobserved skills: evidence from moonlighters in the UK', Manchester School, 77, pp. 651-74.

Oi, W. Y. and Idson, T. L. (1999). 'Firm size and wages', in Ashenfelter, O. and Card, D. (eds), Handbook of Labour Economics, vol. 3, Amsterdam: Elsevier, pp. 2165-214.

Rajan, R. G. and Zingales, L. (2001). 'The firm as a dedicated hierarchy: A theory of the origins and growth of firms', Quarterly Journal of Economics, 116, pp. 805-51.

Silverman, B. W. (1986). Density Estimation for Statistics and Data Analysis, London: Chapman \& Hall/CRC.

Simon, H. A. (1957). 'The compensation of executives', Sociometry, 20, pp. 32-5.

Thaler, R. H. (1989). 'Interindustry wage differentials', Journal of Economic Perspectives, 3, pp. 181-93.

Troske, K. R. (1999). 'Evidence on the employer size-wage premium from worker-establishment matched data', Review of Economics and Statistics, 81, pp. 15-26.

UNSD (2002). International Standard Industrial Classification of All Economic Activities, Revision 3.1 (ISIC Rev. 3.1), UNSD - Economic Statistics and Classifications Section.

Williamson, O. E. (1967). 'Hierarchical control and optimum firm size', Journal of Political Economy, 75, 123-38.

Zàbojnik, J. and Bernhardt, D. (2001). 'Corporate tournaments, human capital acquisition, and the firm size-wage relation', Review of Economics Studies, 68, pp. 693-716. 